\title{
EDUCATION AND ITS IMPORTANCE FOR WOMEN IN BUILDING A COUNTRY'S ECONOMY - Review Article
}

\author{
Faiza Qasmi*
}

Department of General Education. Khawarizmi International College, Post Box Number 25669, Al Ain Abu Dhabi, United Arab Emirates

Email: faizaqasmi27@gmail.com

\begin{tabular}{|c|}
\hline $\begin{array}{c}\text { ABSTRACT } \\
\end{array}$ \\
\hline $\begin{array}{l}\text { Education brings a reduction in inequalities and functions as a means of improving their } \\
\text { status within the family and develops the concept of participation. Education of women is } \\
\text { the most powerful tool to change their position in society. In fact, women are the most } \\
\text { important asset of a society. Women are an important factor that can shape the society. } \\
\text { Even though everybody is aware of this fact, but nobody is ready to accept this fact. In the } \\
\text { present paper we are discussing the role of education and its importance for women in } \\
\text { building a country's economy. }\end{array}$ \\
\hline
\end{tabular}

Keywords: education, country, economy, women, women empowerment.

\section{No: of References: 14}




\section{INTRODUCTION}

Human beings are not achieving anything in their lives, unless they are achieving education. The value of the education is understandable as education is not only helping in the development of half of the human resources, but is improving the quality of life at home and outside. It is rightly said that education is the solution to all problems. The model in several Far Eastern and Middle Eastern countries is of course different. Although the mother and father have traditionally formed the core, it has been a common practice to give members of the community, who are not blood relatives, certain responsibilities in the upbringing of children. Thinkers have given a number of definitions of education but out of these definition, the most important one, is that which was put forth by M. Phule (Jyoti. S. Bamman et al., 2011). According to M. Phule, (Jyoti. S. Bamman et al., 2011) "Education is that which demonstrates the difference between what is good and what is evil". If we consider the above definition, we realize about whatever revolutions that have taken place in our history. Moreover, educated women can also help in the reduction of infant mortality rate and growth of the population.

Women empowerment plays a pivotal role in any society, state or country. It is a woman who plays a dominant role in the basic life of a child. Women are an important section of our society. Education as means of empowerment of women can bring about a positive attitudinal change.
It is therefore, crucial for the socioeconomic and political progress, empowers the state to adopt affirmative measures for prompting ways and means to empower women. Education significantly makes a difference in the lives of women. Women's empowerment is a global issue and discussion on women's political rights are at the fore front of many formal and informal campaigns worldwide. The concept of women's empowerment was introduced at the international women's conference at NAROIBI in 1985.

The increasing change for betterment in women's education, the empowerment of women has been recognized as the central issue in determining the status of women, as per United Nations Development Fund for Women (UNIFEM) the term women's empowerment means:

- Acquiring knowledge and understanding of gender relations and the ways in which these relations may be changed.

- Developing a sense of self-worth, a belief in one's ability to secure desired changes and the right to control one's life.

- Gaining the ability to generate choices and exercise bargaining power.

- Developing the ability to organize and influence the direction of social change, to create a more just social and economic order, nationally and internationally.

Thus, empowerment means a psychological sense of personal control or influence and a concern with actual social influence, political power and legal rights. It is a multi-level construct referring to individuals, organizations and community. 
It is an international, ongoing process centered in the local community, involving mutual respect, critical reflection, caring and group participation, to gain greater access to the control over those who are lacking an equal share of valued resources.

Yet there is still a great amount to be done to establish gender equality. The idea of women as educators, should permeate society. The educational efforts of governments should reach to each and every individual belonging to a downtrodden mass. In this way people will become more open and receptive to new ways of looking at the world and society. Statistics tend to be a reflection of government intervention, and the tools by which governments can not only evaluate their actions, but also anticipate and attend to problems before they become unmanageable. In this respect, the E-9 governments have become fully aware of the need to have reliable research department to maintain the viability of not only educational, but public programs and strategic plans in general.

Another area in which women's equality has shown a major improvement as a result of adult literacy programs is the area of enrolment of boys and girls in schools. As a result of higher participation of women in literacy campaigns, the gender gap in literacy levels is gradually getting reduced. Even more significant is the fact that the disparity in enrolment of boys and girls in neo-literate households is much lowered compared to the non-literate households.
(Hooks, B 2000) The world has achieved equality in primary education between girls and boys. But few countries have achieved that target at all levels of education. The political participation of women keeps increasing. In January 2014, in 46 countries, more than $30 \%$ of the members of the parliament in at least one chamber were women. In many other countries, gender inequality persists and women continue to face discrimination in access to education, work and economic assets, and participation in government. ${ }^{3}$ Women and girls face barriers and disadvantages in every sector in which we work. Around the world, 62 million girls are not in school. Globally, 1 in 3 women will experience gender-based violence in her lifetime. In the developing world, 1 in 7 girls is married before her 15th birthday, with some child brides as young as 8 or 9. Each year more than 287,000 women, 99 percent of them in developing countries, die from pregnancy and childbirth-related complications. While women make up more than 40 percent of the agricultural labor force, only 3 to 20 percent are landholders. In Africa, women owned enterprises make up as little as 10 percent of all businesses. In South Asia, that number is only 3 percent. And despite representing half the global population, women comprise less than 20 percent of the world's legislators. Putting women and girls on equal footing with men and boys, we have the power to transform every sector in which we work. (Kabeer, $N$ 1999) The gender equality and women's empowerment isn't a part of development but is at the core of development. To get 
rid of this we have to make some educational awareness programmes on gender equality and women empowerment for cementing our commitment to supporting women and girls.

Although a legal framework exists that favors women in the education system, in many countries, gender parity is difficult to achieve, due to beliefs that limit the level of empowerment that women can reach. In Bangladesh, people consider women's place is principally in the home, where their tasks are limited to bringing up children and carrying out domestic chores. Therefore, their success in life completely depends on the efficiency with which they play their role as wives and mothers (Karlberg, M 2005) People in Bangladesh consider that as women's knowledge is acquired through informal education, they do not need school, given that the education system do not offer the skills or knowledge suitable for carrying out the responsibilities of a mother. It is believed that the level of education of women should be lower than that of their husbands. It is also thought that educated daughter-in-laws are less willing to adopt the rules, values and discipline of the inlaws. This inferior status of women is related to the traditional role they play in the family and in society. Reasons for sending sons and daughters to school are based on the same value system. The idea that (Pickvance, C 1995) women should better themselves in other fields than the home is not very widespread. For a change to take place, parents must raise their expectations for their daughters, who in turn must be made more aware of their potential by developing their skills. In Bangladesh, Nigeria, Indonesia, Pakistan, India and Egypt, the obstacles to sending sons and daughters to school transcend mere physical obstacles or the need to keep girls at home, fetching water and doing other basic tasks. In these countries the problems are more complex. Ideological, religious and cultural factors legitimize the arrangements found by families or societies to meet their basic needs, although these arrangements cause the marginalization of women. This situation makes it difficult to implement programmes that promote equal opportunities. Religious education is extremely influential and the values that are handed down from generation to generation are not questioned. Several national evaluation documents indicate that some of the established customs that limit the possibilities of women's empowerment differ from those of Islam. In Egypt, there is a strong recognition of the crucial role of women in sustainable development, and the Egyptian government is publicly committed to integrating them into this process. However, inequality is evident in some social and political environments, and has diverse impacts on the life of women from different social classes, limiting their access to education and jobs, as well as their inclusion in the decision-making process. Most Egyptian women stay at home and only go out for work if there is a pressing need. They have to abide by strict moral standards as an example for the other

\section{September Edition | www.jbino.com | Innovative Association}


members of the family. They are also characterized by their spirit of self-sacrifice in the family. In Pakistan, women play an important role in the education of the family, inspired fundamentally by Islam. The most important contribution of women is in the teaching of the Quran, which is the ultimate Divine Book and code of conduct in Islam. Currently, it is estimated that around 60 per cent of Pakistani women are literate in the Quran. Most of these women, in both urban and rural areas, teach the Quran to their children or work in mosques or other Islamic centers. In rural areas, above all, women, grandmothers, mothers and aunts, are fundamental cultural educators; they are the source of information, education and training in topics such as fertility, pregnancy, nutrition, hygiene and health. In ancient times, India had women educators who were brilliant academicians and disciples. However, subsequent traditions related to the dharma or code of ethics, along with successive uprisings and invasions, led to the decline of the social role of women. The age of consent for women fell and no institutional platform for their education was built (Pickvance, C. and E. Preteceille 1991). Although during the colonial years several efforts were made to build an educational structure for women, the reality is that no work was carried out until independence. In Indonesia, the 1945 Constitution enshrines the principle of equality between men and women; however, women and girls still face great obstacles in access to education. Although women work effectively on different projects, they are not considered as indispensable. For example, in concrete production projects promoted by the government (prescott, H.W. 2001) in marginalized areas, only men are considered as full participants even though women spend the same time and effort. For women to advance in the educational field in Indonesia, there must be a change made in attitudes towards them at the level of decision making, planning and leadership. Nigerian women are responsible for feeding, dressing and caring for both girls and boys, for their socialization and integration into the community, and for instructing them in their own cultural standards. In traditional Nigerian communities, ${ }^{12}$ the society is like a school where the educators are parents, members of the extended family and the community. The father also plays an important role in the moral guidance of his children: he is in charge of teaching them customs and traditions. Grandmothers, aunts and other women are responsible for the mother and the newborn baby during the first days of life. In some polygamous homes the first wife supervises the other wives and children. This is especially notable in the Hausa culture, in which the children born to the other women are taken to the first wife, who educates them. In Nigeria, the values of religions such as Christianity and Islam are not ignored. The coexistence of formal education and religious education is considered important. China (Karlberg, M., 2005), Brazil (Pickvance, C.1995) and Mexico (Pickvance, C. and E. Preteceille 1991) differ from the other countries in urban areas; however, in rural, marginalized and 
remote communities, women's role in several aspects, is similar to the other countries. For thousands of years, China (Poulantzas, $\mathrm{N}, 1978$ ) was a country in which a patriarchal society prevailed, and where the values based on Confucianism had a great influence on the perception of women, both by men and by women themselves. The idea that men are above women because the sky is above the earth has prevailed for years. Traditionally, according to the "Three Obedience's" doctrine, when a woman is young she depends on her father and brothers; when she marries (Murphy-Graham, E 2008), she depends on her husband, and when her husband dies, she depends on her sons. The role of women used to be limited to child-rearing. As in all the E-9 countries (Oxaal, Z., Baden, S, 1997), the mother is very important in the education of her sons and daughters.

According to study by Aylin Topal (Pickvance, C. and E. Preteceille, 1991) in Saudi Arabia where gender regime has long been based on male supremacy and state-sanctioned discrimination depriving women of their basic human rights, the study suggests that women's empowerment has been used as a code word to increase the competitiveness of the Saudi economy with a view to increase foreign economic integration. In other countries also, like United Arab Emirates the mindset has changed and they are encouraging their women (Malhotra, A ,2002) to educate themselves and creating opportunities for them to contribute in the development of their rapidly growing economies.

Present studies (Papart, J., Rai, S., Staudt, K,2002) suggest that General awareness programs should be taken among the women to sensitize them about the modern development of science and technology so that they could give up superstitious believes and attitudes. Women of rural areas (Mosedale, S., 2005) should be trained up in different vocational courses like local handicrafts, handloom and textile, poultry farming, fish farming, , dairy farming, food and nutrition, fashion and designing, fitness and beauty salons etc. Women reservation policies should strictly be maintained in all aspects like appointment in govt. and semi govt. offices, admission in the educational institutions, participation in the politics etc.

\section{REFERENCES:}

Jyotirao Phule quoted in Sharanabasappa B. Ragi, Jyoti. S. Bamman (2011), Mahatma Phule and Women's Emancipation International Referred Research Journal,June,p.113

Hooks, B., 2000. Feminism is for everybody. South End Press, Cambridge, MA.

Kabeer, N., 1999. Resources, agency achievements: reflections on the measurement of women"s empowerment. Development and Change 30, 435-464. 
Karlberg, M., 2005. The power of discourse and the discourse of power: pursuing peace through discourse intervention. International Journal of Peace Studies 10 (1), 1-25.

Pickvance, C. 1995. Marxist Theories of Urban Politics, in Theories of Urban Politics, ed. J. David. London: Sage. Pickvance, C. 2001. Four Varieties of Comparative Analysis. Journal of Housing and the Built Environment 16: 7-28.

Pickvance, C. and E. Preteceille (eds). 1991. State Restructuring and Local Power. London, New York: Pinter. Poder Ejecutivo Federal. 1989. Plan Nacional de Desarrollo, 1989-1994. Mexico City: Secretaría de Programación Presupuesto. Poder Ejecutivo Federal, 2000. Plan Nacional de Desarrollo, 1995-2000. Mexico City: Secretaría de Programación Presupuesto

Poulantzas, N. 1978. State, Power, Socialism. London: Verso.

Prescott, H.W. 2001. History of the Conquest of Mexico. New York: Modern Library. Prud'homme R. 1996. The Economics of Decentralization in Very Low Income Countries. Revue Région and Dévelopment 3:155-60.

Malhotra, A., Schuler, S., Boender, C., 2002. Measuring Women"s Empowerment as a Variable in International Development. Paper commissioned by the Gender and Development Group of the World Bank.
Mosedale, S., 2005. Assessing Women"s Empowerment: Towards a Conceptual Framework. Journal of International Development 7 (2), 243-257

Murphy-Graham, E., 2008. Opening the black box: Women's empowerment and innovative secondary education in Honduras. Gender and Education 20 (1), 31-50.

Oxaal, Z., Baden, S., 1997. Gender and Empowerment: Definitions, Approaches and Implications for Policy. BRIDGE Report No. 40. Institute of Development Studies, University of Sussex, Brighton, UK.

Papart, J., Rai, S., Staudt, K. (Eds.), 2002. Rethinking Empowerment: Gender and Development in a Global/Local World. Routledge, London 